\title{
PERSONAL FINANCIAL MANAGEMENT CAPABILITY AMONG EMPLOYEES IN JIMMA TOWN, SOUTHWEST ETHIOPIA: A PILOT STUDY
}

\author{
Matewos Kebede Refera \\ Lecturer, Department of Accounting and Finance, \\ Jimma University, Ethiopia \\ Abiy Getahun Kolech, \\ Assistant Professor, \\ Department of Accounting and Finance, \\ College of Business and Economics, Jimma University, \\ Jimma, Oromia, Ethiopia
}

Doi: 10.19044/elp.v2no2a3 URL:http://dx.doi.org/10.19044/elp.v2no2a3

\begin{abstract}
Personal financial management involves the use of one's financial knowledge and skills in making financial and economic decisions. Various studies suggest the need for providing formal and informal personal financial education and practice in developing nations like Ethiopia. The current study has conducted a pilot study of personal financial management practice among employees in the formal sector in Jimma Town, Ethiopia. The objective of the study is to explore the relationship between education and personal financial management capability of employed adults in the town. This exploratory study is conducted using primary data collected via a selfadministered questionnaire from employed people in the town. Descriptive statistics were employed in addition to other variables both parametric and non-parametric bivariate statistics. The result of the study implies that financial education should be given to employees across all organization for the level of financial management ability is low. In conclusion, government policy makers and academics must follow the global practice of improving personal financial literacy and personal financial management practice in Ethiopia in order to help individuals, which also have implications to improve the operation of the financial system and overall economic performance by considering work place financial education, in addition to in school financial education offered in the country.
\end{abstract}

Keywords: Education, Employees, Ethiopia, Financial Literacy, Jimma, Personal Financial Management Practices 


\section{Introduction}

Personal financial management becomes important academic and policy issue both in developed and developing countries (Xu \& Zia, 2012). According to Elzabith \& et.al (2009) who quoted Deacon \& Firebaugh (1988), "Financial management is a continual processing of information as circumstances change" (p.5) and the expected outcome of financial management is to meet demands (whether long-term goals, short-term goals, or events) by effective use of the resources available to each managerial unit (Donald H \& et. al, 1986).

Personal financial management involves using financial knowledge and skills in making financial and economic decisions including financial savings, credits, insurance, investments, and others. Mounting number of studies on personal finance underscore the need for enhancing personal financial literacy of citizens for the fact that complexity of the financial system, increasing access to credit as well as surging cost of life demand individuals to employ personal financial management practices. Despite a complex knowledge in finance may not be required from every one, basic financial knowledge related to management of money, transactions, selection and usages of financial products are essential to lead a healthy financial life. However, surveys conducted in most countries, including few developing countries showed a low level of personal financial literacy. (Xu \& Zia, 2012)

Literatures (Holzman, 2010; Xu \& Zia, 2012) showed that financial literacy and personal financial management has got policy makers and academic attention in the developed countries, but the effort in developing countries where Ethiopia is included is not that much. However, few of existing empirical studies (Kontze and Smith, 2008; Raja \& et. al, 2011; Nyamty \& Nyana, 2011; Kummar and Annes, 2013) showed that the prevalence of financial illiteracy have been hindering individuals and the economy of various developing and emerging economies for the fact suboptimal financial and economic decisions by individuals do have macroeconomic implications. These studies suggest the need for providing formal and informal personal financial education and practice in developing countries. Nevertheless, we could not come across organized, except the in school financial education currently offered to school children and youth, in the context of Ethiopia.

The current pilot study of personal financial management practice among employees in the formal sector in Jimma Town in Southwest Ethiopia help to identify whether informal financial education such as work place financial education are required to enhance financial capability of Ethiopians. The study is hoped to contribute by showing the personal financial management practice among employed people which could help in shading light whether education and employment contributes to personal 
financial management ability. Moreover, the study could be used as a base for further and comprehensive studies which can inform policy makers, academics and stakeholders on personal finance. Furthermore, it will contribute to personal finance literature in developing countries.

\section{The problem statement}

Financial literacy and personal financial management has become a growing academic and public policy debate in most advanced countries; however, the effort in least developed countries remained limited. Some of the studies showed that people in emerging and developing countries are also suffering from low level of financial literacy which demands policy intervention. Government and other concerned organizations including the private sector in financial service need to consider personal financial education for the fact that it enhances economic decision making ability among the community which will contribute to the development of the financial system and sustainable economic growth. In the context of a developing country, financially literate individuals can contribute to better financial inclusion and development of financial markets. It is also possible to enhance the personal and gross national savings and investments which are grave problems in most developing countries.

Ethiopia, a developing nation, is located in Sub-Saharan Africa and is a home for about 83 million people. The country has been striving to eradicate poverty and ensure sustainable economic development. Among the multi-facet challenges of economic objective of a nation, low level of personal saving and investment which according to studies in financial literacy in developing countries this problem may partly associated with low financial literacy and financial inclusion, can be tackled by enhancing financial literacy and financial inclusion in the country. None of the various studies, conducted in this respect, considered the effect of personal financial literacy as part of the solution albeit it is well documented that low level of financial literacy affected financial sector development and hindered economic growth and development in developing countries (Kefela (2011).

The current study is, hence, aimed at conducting exploratory study on personal financial management capability of educated adults employed in the formal sector in Jimma, Ethiopia. The target population is selected not only because of convenience of data collection but also there existed low level of personal financial literacy among employed in different part of the world. For example; as cited in Kefela (2011), Bernheim (1998) surveyed several studies showed that workers display little financial literacy. The current study is, then, helpful in showing the effect of education on personal financial management capability of employed people which could trigger 
further comprehensive studies, on one hand, and highlight the need for workplace financial education to employees.

\section{Objectives of the study}

The objective of the study is to explore into the relationship between education and personal financial management capability of employed adults in Jimma town, south western Ethiopia. The specific objectives include the following:

- $\quad$ To measure and describe personal financial management capability index among respondents,

- To examine the relationship between education attainment and personal financial management capability,

- $\quad$ To examine whether higher education in business and economics improves personal financial management, and

- $\quad$ To examine whether job position and number of years in paid job improves the personal financial management capability.

\section{Review of related literature}

This section provides review of literatures on the concepts of personal financial management and determinants of personal financial management practice which laid out the study's theoretical framework.

\section{Personal financial management capability}

Personal financial literacy and personal financial management capabilities are the most common terms used in relation to personal financial management practices to be recommended to ensure sustainable financial and economic life of an individuals and the whole economy. Holzeman cited Kempson (2008) to provide a working definition of personal financial capability that shows the domains of financial capability and outcomes of using recommended personal financial management practices, reads as follows:

"A financially capable person is one who has the knowledge, skills and confidence to be aware of the opportunities, to know where to go for help, to make informed choices, and to take effective action to improve his or her financial well-being while an enabling environment for financial capability building would promote the acquisition of those skills"(Holzeman, 2010)

The comprehensive meaning provides a foundation on designing education and training programs as well as conducting study on personal financial management capabilities as it makes clear the financially capable person requires having the knowledge skill in personal finance as well as 
need to develop behavior to realize the importance of using recommended practices.

The concept of personal financial management has been used in various studies, such as the 2009 Canadian Financial Capability Survey (Kewon, 2011), the 2005 UK financial Capability survey (Holzeman, 2010) and other successive studies cited in this paper. The contents of personal financial management practice used in most studies are categorized into a five broad factors, namely: keeping track, making ends meet, planning ahead, choosing products, and staying informed. According to Holzman (2010), the recommended financial management practices could somewhat vary from country to country in response to individual and socio economic factors having a bearing on the financial management practices to be followed though the ultimate goal is similar in all the contexts. Hence, the recommended practices may further include:

- Having a place within the home where all financial documents are kept

- $\quad$ Setting short and long term financial goals

- Having a budget

- $\quad$ Keeping records of household inventories, credit cards, etc.

- $\quad$ Risk management techniques and insurance polices

- $\quad$ The practices are to be done in writing (Goodwin \& Carllon, 1986)

Practice recommended by Lawrance, Carter and Verman (1987) also suggests that preparation of a net worth statement. Net worth, as explained on accounting literatures, refers to net asset or the difference between what one owns and owes. Thus, it seems that individuals need to have personal accounting record and personal balance sheet, which could be difficult to many and less practical. In general, for better use of personal and/or family finance, an effective financial management needs some sort of personal financial records.

According to Elizabeth \& et.al (2009) who quoted Deacon and Firebaugh (1988), "Financial management is a continual processing of information as circumstances change"(p.5) and the expected outcome of financial management is to meet demands (whether long-term goals, shortterm goals, or events) by effective use of the resources available to each managerial unit (Donald H \& et. al, 1986).

Elizabeth \& et.al (2009) cited a number of studies "DeVaney, Gorham, Bechman \& Haldeman, 1995, 1996; Jeries \& Allen, 1991; Titus, Fanslow \& Hira, 1989; Varcoe \& Wright, 1989, [who] showed the positive effects of using selected financial management practices." Elizabeth and colleagues argued that, though studies showed the positive effects of using effective personal financial management techniques, individuals usually 
decline to use either some or all the recommended practices. Thus, it requires effort to teach the practices and convince the importance of personal financial management towards individuals and the whole economy.

Although there are other factors affecting individual's ability and willingness to apply the recommended personal financial management practices in the management of their personal finance, personal financial management education proponents argue that consumers need to acquire knowledge, skill and attitude in personal financial management that can be acquired through formal and informal education programs and experience. The importance of personal financial management education has got popularity for the fact that lack of knowledge or low level of financial literacy was found among the dominant causes of poor personal financial management in both developing and developed countries (Xu \& Zia, 2012).

\section{Importance of personal financial management}

The recent trend in finance and economics in the world made financial knowledge not just a convenience, but essential survival tool (Katy $\&$ et.al, 2000). Consistent with the surging literatures in personal finance, Katy \& et.al (2000) pointed out that lack of financial knowledge leads to poor financial choice and decisions which could harm individuals and community. McCray (2011) also explained importance of personal financial management by showing that poor financial literacy leads to financial distress and bankruptcy. Personal finance education is, hence, relevant to empower the society in management of personal finance and made informed financial and economic decisions. As empirically proved by Elizabeth \& et.al (2009), individuals participated on personal financial literacy programs increasingly appreciated personal financial management techniques and start using either some or all recommended practices. They could also start to enjoy the outcomes in the form of increased saving, improved credit history and ability to meet ends with one's income. Funfgeld and Wang (2009) mentioned personal financial management capabilities do have implications on financial situations in that those with good personal financial management capabilities found to be satisfied with their money management and level of their net worth. In general, optimal personal financial management not only contributes for the betterment of individuals and family socio economic status, but also is essential to a well-functioning financial system and economy (Pelline \& et.al, 2011).

\section{Personal financial capability in developing countries}

Enhancing financial literacy of low income households is paramount for the fact succinctly mentioned by Katy \& colleagues that: 
"Low-income families that lack basic financial skills become more vulnerable to sudden economic shocks such as health emergencies or unexpected job losses. Decreased family stability, increased foreclosure risks, and disinvestment in homes and local businesses challenge already disadvantaged lower-income communities." (Katy \& et.al, 2000: p.3)

The above argument which is in line with M. Cohen \& J. Sebstad (2003) and Holzman (2010) implies that financial literacy in developing countries can contribute to poverty reduction and economic growth.

In the context of least developed countries (LDCs), where the majority of the population living below poverty-line, under low personal and national savings, improved personal financial capability will enhance socioeconomic status of citizens. As mentioned by M. Cohen \& J. Sebstad (2003), financial education can play an important role in reducing poverty in developing countries by building people's knowledge and skills in optimal usage of resource and making optimal financial and economic decisions related, but not limited to: savings, investments, and wealth accumulation which essentially facilitate economic growth and development in a nation.

Albeit literatures underscored the need for enhancing financial literacy of poor people, the current effort of doing the same in developing countries remained scant when one compared the case with the developing countries (Holzman, 2010; Xu \& Zia, 2012). The short and long term life goals of people both in developing and developed nations are alike, which indicate the need to impart personal financial management wisdom existed in developed countries to LDCs. Further, rampant poverty, lack of saving and inability to meet ends with available meager resource in developing countries justify the need for enhancing personal financial capability of individuals in developing countries (Holzman, 2010). Besides, the growing literature on financial inclusion in developing countries have been arguing that financial illiteracy is one of the major demand side problem to financial inclusion in developing countries for the fact that access to financial service without efficient and effective usage of poor customer could not serve the purpose of poverty eradication through access to finance as have been hoped by development policy makers and academics. For example, Shanka (2013) in the study of financial inclusion in India indicated that sustainable financial inclusion through microfinance approach is hampered for the fact that clients may drop out the service for various reasons, including improper use of service and over indebtedness which is partly the result of low financial literacy. In line with this, Custors (2011) who empirically examined the effect of financial literacy programs in the context of Indian microfinance argued on the significance of such studies in various developing countries to develop a model of measuring client financial literacy which help to design 
training programs as well as microfinance service that can enhance client financial knowledge and application of the same in personal financial decision. Tustin (2010) and Cole et al (2014) in the context of South Africa documented the effect of client financial education in enhancing financial management capability of clients. The need to invest in client financial education by financial institutions also contributes to performance of financial institutions and stability of financial sector (Kebed et al (forthcoming), Mundey and Masok; 201).

\section{Factors affecting financial management capability}

Studies identified different factors affecting the use of recommended personal financial management practices. Most of the researches done in the context of high income and developed countries are alike in pointing out that level of financial literacy, demographic, socioeconomic and behavioral factors explains the level of adopting personal financial management practice by individuals (Eltahbet,2009; Donald H. 1986 ). The exploratory study by Holzman (2010) that aimed at bringing wisdoms of personal financial capability from high income and developed countries to low and middle income countries pointed out that other variables such as low level of access to and usage of financial services, level of poverty, informality of the economy, existence of risk, but lack risk management techniques, living in rural area could affect the possibility of adopting personal financial management tools in the context of low income and developing countries.

Elizabeth et al (2009) studied which kinds of financial management education and training programs enhances individual's tendency in adopting recommended personal financial management practices in women financial training programs in three different states in the USA. And, the finding of their study revealed that the number of financial management practices used by individuals passed through the training depends on demographic characteristics. For instance, increase in age showed a significant positive correlation with the number of financial management practice. Being married with a large family size has been found to have negative relationship with the tendency to adopt budgeting practices.

Kewon (2011), on the study of the Financial Knowledge of Canadian, an article that consumes data from the national financial capability survey of Canadian that considered individual demographic characteristics such as age, income, and sex; and the financial behavior indicators such as having budget and investment and other objective-type question quizzes on financial knowledge related with inflation and interest rates, credit reports and credit ratings, stocks and risk, insurance, taxation, debts and loans, and banking fees provided showed that: 
- Level of financial knowledge is related with income. In the study, those with higher income scored high in financial knowledge quizzes. The justification given on the study includes the positive correlation between high income and education, participation in investments. Moreover, as compared to people in low income group, the higher income group seeks various types of financial services which are presumed to enhance their financial knowledge.

- Increase in age especially in the higher income group is associated with higher financial knowledge.

- $\quad H o m e$ owners in the low income group score higher than renters.

- $\quad$ Those who live alone scores higher than those who live with family. The justification for this is that those who live alone have a sole responsibility of fulfilling their needs.

- $\quad$ Self-employed and retired people also scored higher result on financial knowledge quizzes compared to others in the working class.

In addition to demographic, socio-economic factors' practical applicability of personal financial management tolls depends on psychological factors. Elizabeth \& et al. (2009) indicated the importance of incorporating psychological factors while designing and/or evaluating financial literacy programs because favorable perception to personal financial literacy and personal financial management practices leads to number of techniques to be adopted. Similarly, McCarthy (2011) also revealed that behavioral factors like self-control, planning, and patience, affect ability to manage personal finance and stay out of financial trouble. McCarthy (2011) and Roa Garcia (2011) suggested that the impact of behavior considered in order reducing the negative effect of behavioral influencers of personal finical decision making. In support of this recent empirical evidence (for example: Ali \& et al (2013), Juen et al. (2013) showing the effect of some behavioral factors on personal financial management.

\section{The effect of financial management capability}

Hilgert et al (2003) argued that financial literacy and financial management behavior are related albeit there are studies contending conclusiveness of empirical evidences. Their finding also shows the positive relationship between financial literacy and household financial management behavior. Rooij \& et.al (2011) on financial literacy, retirement planning and household wealth also showed a causal relationship between financial literacy and wealth holdings after controlling other determinants of wealth such as income, age, educations, family composition, risk tolerance, patience, and attitude towards saving. Behrman \& et.al (2012) also showed that the financial literacy and education have a positive relationship with 
household wealth accumulation. It is also indicated that the schooling effect only becomes positive when interacted with financial literacy. An impact assessment of personal financial management training by Elizabeth \& et.al (2006) also indicated that trainings have brought impact; however, the extent at which trainees implement training in life depends on demographic, socioeconomic and other factors. In line with this, Caskey (2006) argued that financial literacy education can help low income households to accumulate assets and improve credit history. The literature suggested that improvement in personal financial capability lead to better management of one's financial affair and improved socio economic wellbeing. The study of Sekita (2013) on relationship between financial literacy and wealth accumulation in the context of Japan confirmed previous studies of Behrman, et al (2010) and Rooij et al. (2012) that showed a positive contribution of financial literacy on wealth accumulation. The findings of recent empirical studies justified the ever increasing concern of governments and other institutions to enhance personal financial literacy of citizenry. Despite the fact that publicly funded financial education programs aimed at enhancing financial capability of individuals proliferating and availability of favorable empirical evidences as to the effect, the overall findings not yet conclusive for the fact there are studies showing low or no effect of financial education on enhancing financial management behavior and ultimate outcomes such as improved network (Xu \& Zia, 2012). Yet, recent experimental studies (Custors, 2011), Gin et al (2014), Cole et al (2014)) emerging from developing countries are underpinning the need for furthering a well-designed and targeted financial education in developing countries.

\section{Why employers are concerned about financial literacy of their employees?}

Apart from personal wellbeing financial literacy of employee can contribute to organizational performance. In explaining the point, Marican \& et al. (2012) argued that individual with low level of personal financial capability are prone to financial stress that can affect their physical and mental health. In their study of financially distressed employees at workplace in Malaysia, Marican \& et al (2012) concluded that job performance and work productivity has strong association with financial stress faced by the employees. According to this study, financially distressed employees fail to pay their bills and usually wary about their financial health which in turn could negatively affect their performance at work for the fact that employees could spent working hours by talking about their financial problems and thinking about ways to overcome. Moreover, as their mental and physical health can be affected they may become absent from the job, the medical insurance and expense of the employer can also be increased. As the problem 
can have devastating implication on individual and family as well as their work place performance, employers need to design various strategies to overcome the problem at least as part of their corporate social responsibility effort.

\section{The need for personal financial management studies}

The study of personal finance remains the subject of interest in various disciplines such as home economics/consumer economics, behavioral finance. Funfgeld and Wang (2009) revealed individuals attitude and behavior to daily financial matters as well as their personal management practice can be modified through formal and informal learning experiences they have about financial literacy and financial capability. According to Funfgeld and Wang (2009), to initiate and take various actions aimed at enhancing personal financial management capability, the first step should be studying the attitude, behavior and currently used practices. Consistent with this argument Glen and May (2004), also pointed out that making campaigns to improve personal financial management on the basis of what currently people practicing and the result they obtained enables to get the desired attitudinal change.

The need for studying personal finance has shown growth only in the last ten years. The concern and involvement of local and international financial authorities on financial literacy has been cited as a justification for the importance of the issue. For instance, Pelline \& et.al (2010) mentioned Financial Service Authority (FSA), 2005, 2006a in UK; and the OECD, 2005 as national and international effort to assess financial capabilities of consumers. Holzman (2010) also indicated how governments and various local and international organizations including financial institutions have been working towards the promotion of personal financial education. Holzman offered a list of efforts of stock taking on personal financial capability that can serve in designing and implementing intervention programs to enhance personal financial capability. His list includes: OECD initiative of promoting personal financial management education in the member countries, and agencies created in New Zealand (Retirement Commission, 1995), United Kingdom (Financial Service Authority, 2000), Canada (Financial Consumer Agency, 2001), USA (Financial Literacy and Education Commission, 2003), and Australia (Financial Literacy Foundation, 2005, and since transferred to the Australian Securities and Investments Commission) (Holzeman, 2010).

Holzman (2010) pointed out that the last 10 years provided lesson on the importance of consumer personal financial capability to enhancing individual's wellbeing and building national economy. In developing countries, like Ethiopia, the issue of personal financial management has not 
given attention by academia and policy makers. The recent financial education policy adoption in developing countries (Xu \& Zia, 2012; Kebede et al (forthcoming) should be supported the need for survey of financial literacy and capability level of people to inform better financial education policy and programs.

\section{Materials and methods}

This exploratory study is conducted using primary data gathered as part of research on personal financial management capability and net worth of employed people in the formal organization in Jimma town, funded by Jimma University. The data were collected using a questionnaire from a convenient sample of 56 employees from different organizations operating in Jimma town. For the purpose of addressing the research objective a descriptive statistics were employed to describe the profile of respondents and the mean score of their personal financial management capability under education and job related variables. To examine the relationship between personal financial management capability and other variables both parametric and non-parametric bivariate statistics were employed.

\section{Results and discussions \\ Profile of respondents}

Out of 56 usable questionnaires 22 respondents were females and 34 males. The average age in the sample was 39 . Of total respondent about $86 \%$ have a diploma and above academic qualification out of which $67 \%$ were trained in business and economics related fields which exposed them with basic knowledge of financial management and economics. Though the curriculums are designed in the context of corporate entities, extension to personal financial management could be possible.

The target population of the study was employees in the formal organizations in Jimma town. For the purpose of the study formal organizations are operationally defined as government organizations, large private businesses and not-for-profit non-governmental organizations (NGOs). Of the participants $28(50 \%)$ were government employees and the remaining $8(14.3 \%)$ and $20(35.7 \%)$ were employed in NGOs and private business organizations, respectively.

Majority of respondents $(71.4 \%)$ were working in non-managerial posts, whereas the remaining assumed managerial posts. Employees considered as having managerial position include those who currently assumed coordinator, first level, middle level and top level management posts. The job related characteristics also include number of years in paid jobs and in current position. The number of years in paid jobs affects the personal management capability for the fact that the more individuals in 
formal job assignment, the more will be the ability of planning and executing responsibilities including proper management of owns income. The descriptive statistics of these variables showed that on average respondents had been in a paid job for 8 years $($ St.Dev $=6.81)$ and remained in their current post for an average of 3.21 years $(\mathrm{St} . \mathrm{Dev}=3.46)$. Respondents in management position accounted $28.6 \%$ of the sample and the mean years in the post were 3.3 (St.Dev $=1.75$ ). Having a majority in non-managerial position and few years of management experience in those who assumed managerial responsibility, it could be possible to get lower level of personal financial capability and resulting outcomes.

\section{Personal financial management practices}

Personal financial management refers to using financial and economic concepts in the management of one's financial resources and daily use of money. Based on the review of literature, common personal financial management practices and indicators of personal financial capabilities such as: "keeping track of financial matters, making ends meet, planning ahead, choosing products, and staying informed" were measured using 13 five-point Likert-Scale type questions where "1" refers to the respondent not at all used the suggested financial management practice, " 2 " refers to rarely used, "3" sometimes used, " 4 " frequently used, and " 5 " always used. The statements, measuring personal financial literacy, were developed based on the literature review. The reliability of data collected, under this section, was tested using Cronbach's Alpha with a value of 0.775 for all items. A composite index of personal financial management capability (CPFMCI) was also calculated by combining the self-reported measures of personal financial management practices used by respondents. The smallest possible score is $13(1 \times 13)$ and the maximum possible composite index, in a case where the respondent used all suggested tolls always, is $65(5 \times 13)$.

The mean value of overall CPFMCI among the sample was 31.7308 (St.Dev $=8.99916)$. The result is not remarkable for the fact that it is lower than 50 percent of the maximum expected value of the index. This suggests that personal financial management practices are not widely used by employed people in Jimma town. The finding is consistent with the existing literature in other developing countries. For instance, Nyamute \& Maina (2011) who studied the context of employees in financial sector of Kenya, and Rajna et.al (2011) who studied the context of medical workers in Malaysia also obtained similar results in that personal financial management practices used by employees in these countries suggested that personal financial management capability of employees in developing countries is found at lower level. 
The overall index, in the foregoing paragraph, was constructed out of response to 13 Likert-Scale items. The mean and standard deviation to each of suggested tools of personal financial management are given on table 1 below and the results are discussed under five sub-headings, namely: keeping track of financial matters, making ends meet, planning ahead, choosing products, and staying informed.

Table 1: Reliability Statistics of Items Used to Measure Personal Financial Management

\begin{tabular}{c|c|c}
\hline \hline Cronbach's Alpha & Cronbach's Alpha Based on Standardized Items & N of Items \\
\hline \hline .775 & .742 & 13 \\
\hline
\end{tabular}

Source: Questionnaire Survey 2012

Table 2: Descriptive Statistics on Suggested Personal Financial Management

\begin{tabular}{c|c|c|c}
\hline \hline & Mean & $\begin{array}{c}\text { Std. } \\
\text { Deviation }\end{array}$ & N \\
\hline \hline 1. Budgeting monthly income and expenditure & 3.2800 & 1.44335 & 50 \\
\hline 2. I spending money according to my plan & 3.2000 & 1.48461 & 50 \\
\hline 3. I keep records of income and expenditure & 2.8000 & 1.53862 & 50 \\
\hline 4. Have a regular saving account in bank & 2.6000 & 1.61624 & 50 \\
\hline 5. Saving other than in bank & 1.7600 & 1.25454 & 50 \\
\hline 6. Received loan from bank & 1.4800 & .86284 & 50 \\
\hline 8. Received loan from other sources & 1.6400 & .89807 & 50 \\
\hline 9. Participate in 'Edir' (an indigenous informal insurance for & 2.0800 & 1.17526 & 50 \\
\hline accidents and death) & 2.6800 & 1.95292 & 50 \\
\hline 10. Buy insurance coverage of any kind & 1.1600 & .54810 & 50 \\
\hline 12. Follow business news & 2.9200 & 1.27520 & 50 \\
\hline 13. Considered economic trends in financial decisions & 3.1600 & 1.39035 & 50 \\
\hline
\end{tabular}

Source: Questionnaire Survey 2012

\section{Personal financial planning practice}

As shown on Table 2, the mean value of items used to measure budgeting, spending as per the budget were both around 3.2 with standard deviation of about 1.5. Though with high variability, the average response showed that respondents had some experience of budgeting monthly income and expenditures as well as making their payment as per the budget.

\section{Recording income and expenditure}

The average response for the item measuring this question (item 3) was in between 2 and 3 showing that financial recording habit is not satisfactory. Though majority used budget unless there is records of actual income and spending it is less likely to control spending patterns. Moreover, evaluation of personal/or family financial performance on regular basis can be made if one has both budget and actual income and expenditure records. 


\section{Financial service usage}

Appropriate usage of services from financial institutions indicates financial capability of individuals. A good personal financial management requires proper identification of financial service that ensures optimal use of money and other advantages. As Ethiopia is a developing country with significant portion of the population neither have access to nor knowledge to financial service, both formal and informal financial services usage were considered as measure of financial capability.

The mean response of using bank saving and loan service were 2.6(St.Dev=1.6) and 1.48(St.Dev $=0.86$ ), showing that most respondents are not using basic banking services. An MFI has become important service provider for many people both in urban and rural Ethiopia, but the level of usage among employed people in Jimma town seems very low for the mean response to use services of MFIs was about 1.6, which is between not at all and rarely response categories.

Concerning informal saving and credit services, the mean responses were 1.76 and 2.08(item $5 \& 8$ ) showing that most respondents were not beneficiaries of informal financial services as well. Of course, the frequency of respondents with no saving is high among the sample. Those using non formal credit sources were also similarly high which might suggest that financial services are not popular among employed people.

\section{Choosing products and staying informed}

Individuals need to have prior market assessment to purchase goods and services. At least, one needs to compare prices of goods and services among suppliers, to have information about the business and economic trends before making major financial and economic decisions such as buying property, saving, taking loan and others. To measure such type of practices among the sample, three items were included in the questionnaire (item 11, $12 \& 13$ ) and the result showed that the mean value of comparative buying was 2.92, which means most respondents exercise comparative buying either rarely or sometimes. With regard to following business news and taking into account economic trends in major financial and economic decisions, most respondents fall in between sometimes and frequently response categories implying that uninformed financial and economic decisions could challenge financial and economic health of employees in the town.

\section{Educational and personal financial management practice Education in general and cpfmci}

As learned from description of sample characteristics, educational qualification in the sample ranges from high school to advanced university 
degrees. The mean values of composite personal financial management index (CPFMCI) across level of educational qualification are given in table below. Table 3: Composite Personal Financial Management Capability Index (CPFMCI) by Maximum Educational Qualification

\begin{tabular}{c|c|c|c}
\hline \hline Current Level of Educational Qualification & Mean & N & Std. Deviation \\
\hline \hline Completed High School & 31.1429 & 7 & 5.20988 \\
\hline College Diploma & 36.5556 & 18 & 9.51916 \\
\hline First Degree & 27.8947 & 19 & 9.54460 \\
\hline Second Degree and Above & 30.5000 & 8 & 3.25137 \\
\hline Total & $\mathbf{3 1 . 7 3 0 8}$ & $\mathbf{5 2}$ & $\mathbf{8 . 9 9 9 1 6}$ \\
\hline
\end{tabular}

Source: Questionnaire Survey 2012

As can be seen from Table 3, the mean value of CPFMCI varies across the level of education. Respondents with college diploma and high school graduates scored the first and second highest average composite personal financial management capability index respectively. The average indices for that university degree and above were below sample mean. It seems that higher education attainment above diploma level contributes less to personal financial management capability. To examine the association between educational qualification, a nominal scale variable, and CPFMCI, a ratio scale variable, eta statistic was computed and presented in Table 4 below.

Table 4: Association between Composite Personal Financial Management Capability Index (CPFMCI) and Maximum Educational Qualification

\begin{tabular}{c|l|l}
\hline \hline & Eta & Eta Squared \\
\hline \hline CPFMCI * Educational Qualification & .416 & .173 \\
\hline Source: Questionnaire Survey 2012 &
\end{tabular}

The eta statistic was used to measure the strength of association between educational qualification and personal financial management capability index showed a moderate positive association $(E t a=0.416)$. The result indicates that educational qualification had a direct implication on personal financial management capability. The result, in this respect, to some extent confirmed Xu \& Xia (2012) \& Kummer \& Annes (2013) who argued that educational attainment determines personal financial management capability. Despite the apparent association between education and better personal financial management capability in the study is intuitive and supported existing literature, the overall finding is not impressive. As shown on Table 1 above, the average index of the sample is below 50 percent of the highest possible index which showed that employees in Jimma, Ethiopia do not used most personal financial tolls albeit majority of the sample are educated. 


\section{Education in business and economics and cpfmci}

Education in business and economics disciplines familiarizes graduates with basic financial knowledge and skills that can be applied in the management of personal finance. It was also empirically proven by Nyamty \& Nyana (2011) in their study of personal financial management practice among employees in Kenya found that employees having business and economics background are better in personal financial management than those with non-business and economics background. The current study also tried to figure out whether education in business and economics improves personal financial management capability. And, the results are summarized in Table 5 below.

Table 5: Composite Personal Financial Management Capability Index (CPFMCI) by Field of Education

\begin{tabular}{l|l|l|l}
\hline \hline Field of Specialization & Mean & N & Std. Deviation \\
\hline \hline Business and Economics Related & 33.13 & 35 & 9.019 \\
\hline Non Business Related & 28.56 & 17 & 8.36 \\
\hline Total & 31.63 & 52 & 8.99 \\
\hline
\end{tabular}

Source: Questionnaire Survey Data, 2012

Table 6: Measures of Association

\begin{tabular}{c|c|c}
\hline \hline & Eta & Eta Squared \\
\hline \hline SMEAN (CPFMCI) * Field of Specialization & .241 & .058 \\
\hline \multicolumn{2}{c}{ Source: Questionnaire Survey 2012}
\end{tabular}

Source: Questionnaire Survey 2012

The result on Table 5 revealed that average personal financial management capability index of employees with business and economics background is better than the average index of those with non-business and economics related background. But, the association between field of specialization and CPFMCI measured by eta value on Table 6 , was found to be week (eta $=0.241$ ). Though the association seems weak the result suggested that college education in business and economics area contributes to better personal financial management capability evidenced by the fact that average index of the sample category with business and economics background is higher than the sample mean index. The result in this respect is supported by previous study in other developing country, Kenya (Nyamty \& Nyana, 2011) which enables to surmise that financial education to some extent improves personal financial management capability.

\section{Relationship between job-related characteristics \& cpfmci}

The job specific characteristics considered in the study includes the type of organizations, number of years in a paid jobs, position and number of years served in the current position. 
Table 7: Composite Index of Personal Financial Management (CPFMCI) by Type of Organization

\begin{tabular}{l|l|l|l}
\hline \hline $\begin{array}{l}\text { Type of Organization where Employees } \\
\text { Working }\end{array}$ & Mean & N & Std. Deviation \\
\hline \hline Civil Servant & 28.3333 & 18 & 6.36165 \\
\hline Government Development Enterprises & 35.3333 & 6 & 6.59293 \\
\hline Local NGO & 25.6667 & 6 & 8.45380 \\
\hline International NGO & 27.0000 & 2 & .00000 \\
\hline Private Business Organization & 36.0000 & 20 & 10.13592 \\
\hline Total & 31.7308 & 52 & 8.99916 \\
\hline
\end{tabular}

Source: Questionnaire Survey Data, 2012

Employees in large private business organizations and government development enterprise (GDEs), both of which are profit oriented, scored the first and second highest mean composite index of personal financial management capability. The third highest mean is among civil servants followed by international and local NGOs employees. To measure the strength of association between personal financial capability and type of organization where respondents had been working eta statistics were computed (eta $=0.471)$. This shows a modest association between type of organization where employees had been working and their personal financial management capability index. The measure of association is nearer to 0.5 and the eta squared (0.222) implying that the variables shared about $22 \%$ of their variation.

Total number of years in paid jobs is the other variable considered with an assumption that the more employees at paid job, the better exposure they could have to management of personal and organizational resources; which in turn contribute to personal financial management capability. For the purpose, the mean and standard deviation and Pearson correlation coefficient were calculated

Table 8: Composite Index of Personal Financial Management (CPFMCI) and Years in Paid

\begin{tabular}{c|c|c|c}
\multicolumn{4}{c}{ Jobs } \\
\hline \hline & Mean & Std. Deviation & $\mathrm{N}$ \\
\hline \hline Total number of years in a paid jobs & 8.0000 & 6.80374 & 56 \\
\hline
\end{tabular}

Source: Questionnaire Survey Data, 2012

The mean number of years at paid jobs in the sample is 8 years with standard deviation of 8.67. To examine the relationship between personal financial capability and number of years in paid job, Pearson correlation coefficient was used for both variables as measured at a ratio level. 
Table 9: Correlations between CPFMCI and Total Number of Years in Paid Jobs

\begin{tabular}{|c|c|c|c|}
\hline & & $\begin{array}{c}\text { Composite Index of } \\
\text { Personal Financial } \\
\text { Management } \\
\end{array}$ & $\begin{array}{c}\text { Total Number of } \\
\text { Years in a Paid } \\
\text { Job } \\
\end{array}$ \\
\hline \multirow{3}{*}{ CPFMCI } & $\begin{array}{c}\text { Pearson } \\
\text { Correlation }\end{array}$ & 1 & .240 \\
\hline & Sig. (2-tailed) & & .075 \\
\hline & $\mathrm{N}$ & 56 & 56 \\
\hline \multirow{3}{*}{$\begin{array}{c}\text { Total Number of } \\
\text { Years in a Paid } \\
\text { Job }\end{array}$} & $\begin{array}{c}\text { Pearson } \\
\text { Correlation } \\
\end{array}$ & .240 & 1 \\
\hline & Sig. (2-tailed) & .075 & \\
\hline & $\mathrm{N}$ & 56 & 56 \\
\hline
\end{tabular}

Source: Computed from Questionnaire Survey Data, 2012

The result on Table 9 indicated a low, but statistically significant correlation $(r=0.24 ; p<0.1)$; implying that being employed is not related to personal financial management ability. The finding in this respect is similar with Raja \& et.al (2011), who concluded that employees in Malaysian health sector lacks personal financial capability, though they are interested to manage their personal finance. The other job specific characteristic was position at the job.

Table 10: Composite Index of Personal Financial Capabilities (CPFMCI) by Position at Work

\begin{tabular}{c|c|c|c}
\hline \hline Position in Their Job & Mean & N & Std. Deviation \\
\hline \hline Managerial & 31.1429 & 14 & 12.45828 \\
\hline Non managerial & 31.9474 & 38 & 7.54427 \\
\hline Total & 31.7308 & 52 & 8.99916 \\
\hline
\end{tabular}

Source: Questionnaire Survey Data, 2012

The result in Table 10 showed that the mean personal financial management capability index of employees in managerial and nonmanagerial posts appeared similar. The standard deviations also showed that an index for non-managerial employee seemed less variable than employees in managerial tasks. To examine the association between position at the job and personal financial capability a Pearson correlation coefficient was employed using number of years at the current post and CPFMCI, which are both scale variables. 
Table 11: Correlations between CPFMCI and Number of Years at the Current Position

\begin{tabular}{c|c|c|c}
\hline \hline & & CPFMCI & $\begin{array}{c}\text { Number of Years } \\
\text { Served in the Current } \\
\text { Position }\end{array}$ \\
\hline \hline \multirow{2}{*}{$\begin{array}{c}\text { Composite Index of Personal } \\
\text { Financial Capability } \\
\text { (CPFMCI) }\end{array}$} & $\begin{array}{c}\text { Pearson } \\
\text { Correlation }\end{array}$ & 1 & .075 \\
\cline { 2 - 4 } & Sig. (2-tailed) & & .596 \\
\cline { 2 - 4 } & $\mathrm{N}$ & 52 & 52 \\
\hline \hline \multirow{2}{*}{$\begin{array}{c}\text { Number of Years Served in } \\
\text { the Current Position }\end{array}$} & $\begin{array}{c}\text { Pearson } \\
\text { Correlation }\end{array}$ & .075 & 1 \\
\cline { 2 - 4 } & Sig. (2-tailed) & .596 & \\
\cline { 2 - 4 } & $\mathrm{N}$ & 52 & 56 \\
\hline
\end{tabular}

Source: Computed from Questionnaire Survey

Consistent with the result of mean difference analysis on Table 8 , the Pearson correlation on Table 11 indicates position at work and personal financial management capability index are uncorrelated. This implied that the prevailing low level of personal financial management capability among employees in Jimma, Ethiopia is alike for both managerial and nonmanagers.

\section{Conclusion and suggestions}

The results of the study indicate that employed persons in Jimma, Ethiopia are not using suggested best practices in personal financial management. The overall average personal financial management capability index computed from the survey responses to the 13 Likert-Scale questions is below 50\%. Though previous studies indicated that educational attainment in general and exposure to business and economics courses in particular improves personal financial management ability, this pilot study did not show a major difference between different levels of education for the fact that the mean differences is slightly between various categories. Moreover, the study could not establish a strong positive relationship between educational attainment and personal financial management as both the general education and education in business and economics are found with weak association with the personal financial management practice used by employees. The study also reveals that financial management practice did not vary across employees in different organization both at managerial and non-managerial posts.

Findings of the study, in general, lead to suggest that personal finance education should be given to employees at all level in order to improve personal financial management ability of employees who are responsible not only to optimally utilize their income to meet their personal needs, but also supports significant number of their dependent family members. Moreover, the relationship between negative outcomes of poor personal financial 
management such as financial distress and employee performance as well as productivity is empirically proved on the literature. Hence, personal financial literacy should be considered relevant by employers as well. Workplace financial education through formal and informal ways, therefore, can be considered as one way of intervention to improve basic financial knowledge, skills and attitude of employees on personal financial management (Garman, 1999; Delafrooz \& Paim, 2011). It is also suggested on Yadollahi \& Paim in their study of family financial management that, "To solve the economic problems we need to improve the economic status of families who fail to manage their budget, which results in high debt levels and a lack of personal savings. "Yadollahi \& Paim, 2011: p.1) Besides, government policy makers and academics must follow the global practice of improving personal financial literacy (Holzman, 2010) and personal financial management practice in Ethiopia which can contribute towards enhancing the development of financial system and the overall economy. When we look at the effort at the national level the Federal Government of Ethiopia is appreciated for its effort to include financial literacy in school curriculums under Civics and Ethical Education from grade 4 to grade 12. Nevertheless, most of the sample in this survey that completed school prior to the adoption of this financial literacy policy demands some form of special programs to be effected at work place or in other alternative channels.

\section{References:}

Ali, A., Rahman, Mohd S. A., \& Bakar, A. (2013): "Financial Literacy and Satisfaction in Malaysia: A Pilot Study," International Journal of Trade, Economics and Finance, Vol. 4, No. 5, PP. 319-324

Behrman, J.R., Olivia S. Mitchell,S., Cindy, S. \& David, B.2010. Financial Literacy, Schooling, and Wealth Accumulation. PARC Working Paper Series, WPS 10-06, Available at Scholarly Commons [online] http://repository.upenn.edu/parc_working_pa, [Accessed September 201]

Behrman. J.R, Mitchell, S., \& David, B. 2012. How Financial Literacy Affects Household Wealth Accumulation, Am Econ Rev.,102(3), pp. 300304, available at http://www.ncbi.nlm.nih.gov/pmc/articles/PMC3554245/pdf/nihms400812.pdf [Accessed September 2014]

Caskey, J., 2006. Can Personal Financial Management Education Promote Asset Accumulation by the Poor? Networks Financial Institute Policy Brief No. 2006-PB-06. Available at SSRN: http://ssrn.com/abstract=923565 [Accessed June 2012]

Cole, S., Zia,B., Abel, M., Crowley, L., Pauliac, C.S., \& Postal, V. (2014): "Evaluation of Old Mutual's on The Money Program: Financial Literacy in South Africa," Edited By Mattias Lundberg And Florentina Mulaj, 
Enhancing Financial Capability And Behavior In Low And Middle-Income Countries, Pp.151-494, , The World Bank, Washington D.C

Custors, A. 2011.Furthering Financial Literacy: Experimental Evidence from Financial Literacy Programs for Microfinance Clients in Bohapal, India, Working Paper Series No 11-113, Development Studies Institute, London School of Economics, London, [online] available at www.lse.ac,uk/depts/destin

Custors, A., (2011): "Furthering Financial Literacy: Experimental Evidence from Financial Literacy Programs for Microfinance Clients in Bohapal, India," Working Paper Series No 11-113,Development Studies Institute, London School of Economics, London, [online] at www.lse.ac,uk/depts/destin [Accessed on June 2014]

Delafrooz, N. \& Paim,H. L. 2011. Determinants of Financial Wellness among Malaysia Workers, African Journal of Business Management [ejournal], 5(24), pp. 10092-10100, Available at http://www.academicjournals.org/AJBM, [Accessed September 2014]

Donald, H., Granbois, Dennis L., Rosen, \& Franklin A. 1986. A Developmental Study of Family Financial Management Practices", in NA Advances in Consumer Research Volume 13, eds. Richard J. Lutz, Provo, UT: Association for Consumer Research, Pages: 170-174.

Elizabeth. E, G, Sharon A. D, Janet C. B. 2009. Adoption of Financial Management Practices: A Program Assessment, Journal of Extension [ejournal] available at http://www.joe.org/joe/1998april/a5.php [Accessed June 2011]

Gine, X., Karlan, D., \& Ngatia, M. (2014): "Social Network, Financial Literacy and Index Insurance: Evidences from a Randomized Experiment in Kenya," Edited By Mattias Lundberg and Florentina Mulaj, Enhancing Financial Capability and Behavior in Low and Middle-Income Countries, PP.196-208, , The World Bank, Washington D.C

Hilgert, Marianne A., Hogarth, Jeanne M. and Beverly, Sondra G. (2013): "Household Financial Management: The Connection between Knowledge and Behavior," Federal Reserve Bulletin, July 2003, pp.310-322

Holzmann, R. (2010): "Bringing Financial Literacy and Education to Low and Middle Income Countries: The Need to Review, Adjust, and Extend Current Wisdom," World Bank, IZA and CES, [online] at http://erepository.uonbi.ac.ke:8080/xmlui/handle/123456789/9897.

[Accessed June 2012]

Holzmann, R. 2010. Bringing Financial Literacy and Education to Low and Middle Income Countries: The Need to Review, Adjust, and Extend Current Wisdom, World Bank, IZA and CES, available [online] at http://erepository.uonbi.ac.ke:8080/xmlui/handle/123456789/9897, [Accessed June 2012] 
Juen, Teo T., Sabri, Mohamad F. Abd Rahim, H., Othman, Mohd A., \& Muhammad Arif, Afida M. (2013): "The Influence of Financial Knowledge, Financial Practices and Self-Esteem on Money Management Skills of Young Adults," Malaysian Journal of Youth Studies, PP.24-37, Institut Penyelidikan Pembangunan Belia Malaysia

Katy J., Sharyl H. and Malcolm B., (2000).Tools for Survival: An Analysis of Financial Literacy Programs For Lower-Income Families, Woodstock Institute, 407 S. Dearborn, Chicago, IL 60605, (312) 427-8070, available [online] at www.nonprofit.net/woodstock, last [Accessed on June 2012]

Kebede, R. M., Navkiranjit Kaur D. \& Jasmindeep, Kaur. (2015): "Financial literacy for developing countries in Africa: A review of concept, significance and research opportunities," Journal of African Studies and Development (forthcoming)

Kefela. G, 2011. Implications of Financial Literacy in Developing Countries, African Journal of Business Management, [e-journal] 5 (9), pp. 3699-3705, Available at http://www.academicjournals.org/AJBM,[Accessed March 2014]

Keown, L. 2011. The financial knowledge of Canadians, Canadian Social Trends; 9 abstract only) Spring2011, Issue 91, preceding p30, available at http://connection.ebscohost.com/c/articles/62826281/financial-knowledgecanadians [Accessed September 014]

Keown, L. 2011. The Financial Knowledge of Canadians, Component of Statistics Canada Catalogue no. 11-008-X, Canadian Social Trends, pp.3039

Kotzè, M. \& Smit A. 2008. Personal Financial Literacy and Personal Debt Management: the Potential Relationship with New Venture Creation: SAJESBM NS, 1 (1), pp.35-50

Kumar,S. \& Anees. 2013. Financial Literacy \& Education: Present Scenario in India. International Journal of Engineering and Management Research [ejournal], 3(6), PP. 83-87, available at www.ijemr.net, [Accessed June 2014]

Lewis, S. and F. Messy. 2012. Financial Education, Savings and Investments: An Overview, OECD Working Papers on Finance, Insurance and Private Pensions, No. 22, OECD Publishing. Available at http://dx.doi.org/10.1787/5k94gxrw760v-en [Accessed June 2013]

M. Cohen \& J. Sebstad. 2003. Financial Education For The Poor, Working Paper\#, Microfinance Opportunities, Washington, DC , available [online] at www.microfinanceopportunities.org,[Accessed May 2013]

Marican, S. Bte zakaria, R. \& Abdulrahman, A. (2012), Stressed Employees at Workplace: A Malaysian Perspective, International Journal of Research in Social Sciences,[e-journal] Vol.2 (2) available at < http://www.ijmra.us> [Acceded June 2013] 
McCarthy. 2011. Behavioral Characteristics and Financial Distress, European Central Bank Working Paper Series, No 1303 / F February 2011 [Online] available at <the Social Science Research Network electronic library at http://ssrn.com/abstract_id=1761570> [Accessed July 2013]

Mundey and Masok (Kindly Provide initials) (2011). "Towards an Effective Framework for Financial Literacy and Financial Consumer Protection in Uganda

Nayebzadeh,S., Taft,M \& Mohammadi. 2013. The Study of University Professors' Financial Literacy. International Journal of Academic Research in Accounting, Finance and Management Sciences [e-journal] 3 (3), pp. 111117 available at www.hrmars.com, [Accessed May 2014]

Nyamute, W. \& Maina, M. 2011. Effect of Financial Literacy on Personal Financial Management Practices: A Case Study of Employees of Finance and Banking Institution, University of Nairobi Electronic Repository

Osteen, S., Muske G., \& Jones, J. (2007): "Financial Management Education: Its Role in Changing Behaviors," Journal of Extension, Vol.45 (3), [online] www.joe.org/joe/2007/jue/rb2.php [Accessed on February, 2014]

Rajna, E., Junid \& Moshiri, H. 2011. Financial Management Attitude and Practice among the Medical Practitioners in Public and Private Medical Service in Malaysia, International Journal of Business and Management [ejournal] 6 (8), available at www.ccsenet.org/ijbm, [Accessed March, 2014]

Roa Garcia, J.M. (2011): "Financial Education and Behavioral Finance: New Insights into The Role of Information in Financial Decisions," Journal of Economic Surveys (2011) Vol. 00, No. 0, pp. 1-24, <doi: 10.1111/j.14676419.2011.00705.x>, Blackwell Publishing Ltd, 9600 Garsington Road, Oxford OX4 2DQ, UK and 350 Main Street, Malden, MA 02148, USA.

Robb,A. \& Wodyard A., 2011. Financial Knowledge and Best Practice Behaviors, Journal of Financial Counseling and Planning, 22 (1), PP. 60-70 Rooij,M.V., Lusardi,A. \& Alessie,R.J. 2011. Financial Literacy, Retirement Planning, and Household Wealth, NBER Working Paper No. 17339, JEL No. D12, D91, J26, [online] at http://www.nber.org/papers/w17339 [Accessed May 2012]

Sekita, S. 2013. Financial Literacy and Wealth Accumulation: Evidence from Japan, Discussion paper series, No.2013-01, Graduate School of Economics, Kyoto Sangyo University, Motoyama-Kamigamo, Kita-ku, Kyoto, Japan,[online] available at https://www.kyotosu.ac.jp/department/ec/pdf/2013-1.pdf, [Accessed September 2014]

Shankar, S. 2013. Financial Inclusion in India: Do Microfinance Institutions Address Access Barriers?. ACRN Journal of Entrepreneurship Perspectives, 2 (1), p. 60-74 
Suriya Murithi, B.Narayanan \& M.Arivazhagan,. 2012. Investors Behavior in Various Investment Avenues - A Study, International Journal of Marketing and Technology, [online] available at http://www.ijmra.us, [Accessed January, 2012]

Tustin, Harold, D. (2010). "An Impact Assessment of A Prototype Financial Literacy Flagship Programme In A Rural South African Setting", African Journal of Business Management Vol. 4(9), pp. 1894-1902, 4 August 2010, Available online <at http://www.academicjournals.org/AJBM, [Accessed on January 15, 2015]

$\mathrm{Xu}, \mathrm{L}$. \& Zia, B. (2012). 'Financial Literacy Around The World: an overview of the evidence with practical suggestions for the way forward', Policy Research Working Paper 6107, The World Bank Development Research Group, Finance and Private Sector Development Team, June 2012 Yadollahi, M. \& Paim, L.H. 2011. A Theoretical Study of Family Resource Management. Journal of American Science, 2011; 7(2) [online] available athttp://www.americanscience.org, [Accessed September 2014] 